\title{
Akibat Hukum Pembuatan Akta Penyesuaian Bagi Yayasan Yang Didirikan Sebelum Lahirnya Undang-Undang Yayasan Yang Tidak Sesuai Dengan Peraturan Perundang-Undangan
}

\author{
Raudah Mardanni Pindri \\ Magister Kenotariatan Fakultas Hukum Universitas Islam Indonesia Yogyakarta Indonesia \\ Jln. Cik Di Tiro No. 1 Yogyakarta Indonesia \\ raudah.paci@gmail.com
}

\begin{abstract}
Abstrack
This study aims to examine the making of an adjustment deed to a foundation established before the Law on Foundations was enacted and to analyze the legal consequences of making an adjustment deed that is not in accordance with the laws and regulations. The method used is normative research with a statutory approach. The results of the study conclude that the making of the foundation adjustment deed can be adjusted to the provisions of Article $15 \mathrm{~A}$ and $37 \mathrm{~A}$ of Government Regulation No. 2 of 2013 with the status of the foundation. In addition, the making of an adjustment deed that is not in accordance with the regulations causes certain legal consequences for members of the foundation, notary or the deed made. Foundation members who are proven to have violated the rules can be subject to criminal sanctions as well as the notary can be held civil or administrative responsibility, while the deed can be declared null and void.
\end{abstract}

Key Words: Deed adjustment; notary; legal consequences

\begin{abstract}
Abstrak
Penelitian ini bertujuan untuk mengkaji pembuatan akta penyesuaian terhadap yayasan yang didirikan sebelum lahirnya Undang-Undang Yayasan dan menganalisis akibat hukum pembuatan akta penyesuaian yang tidak sesuai dengan peraturan perundang-undangan. Metode penelitian yang digunakan ialah penelitian normatif dengan pendekatan perundang-undangan. Hasil penelitian menyimpulkan bahwa pembuatan akta penyesuaian yayasan dapat disesuaikan dengan ketentuan Pasal 15 A dan 37 A Peraturan Pemerintah Nomor 2 Tahun 2013 dengan status yayasan tersebut. Selain itu, pembuatan akta penyesuaian yang tidak sesuai dengan peraturan menyebabkan akibat hukum tertentu bagi anggota yayasan, notaris maupun akta yang dibuat. Anggota yayasan yang terbukti menyalahi aturan dapat dikenakan sanksi pidana begitu juga notaris dapat dikenakan tanggung jawab secara perdata ataupun administratif, sedangkan terhadap akta dapat dinyatakan batal demi hukum.
\end{abstract}

Kata-kata Kunci: Penyesuaian akta; notaris; akibat hukum 


\section{Pendahuluan}

Yayasan sudah dikenal sejak pemerintahan Hindia Belanda. ${ }^{1}$ Pada waktu itu lembaga yang kenal dengan nama "stichting" ini dipergunakan oleh para pendirinya sebagai wahana untuk melakukan kegiatan sosial. Pada saat ini keberadaan yayasan diakui berdasarkan Undang-Undang Nomor 16 Tahun 2001 tentang Yayasan yang telah direvisi melalui Undang-Undang Nomor 28 Tahun 2004 tentang Perubahan atas Undang-Undang Nomor 16 Tahun 2001 tentang Yayasan selanjutnya disebut Undang-Undang Yayasan 2004. Kelahiran Undangundang ini dimaksudkan untuk memberi pemahaman kepada masyarakat mengenai yayasan, menjamin kepastian dan ketertibaan hukum, serta mengembalikan fungsi yayasan sebagai pranata hukum dalam rangka mencapai tujuan tertentu di bidang sosial, keagamaan, dan kemanusiaan. ${ }^{2}$

Berlakunya Undang-Undang Nomor 16 Tahun 2001 melegitimasi adanya 2 bentuk yayasan, yaitu yayasan yang lahirnya sebelum Undang-Undang dan Yayasan yang lahirnya setelah berlakunya Undang-Undang Yayasan. Demi menghindari persoalan terkait status yayasan yang sudah berdiri sebelum lahirnya Undang-Undang, Undang-undang Yayasan telah mengantisipasinya yaitu melalui Pasal 71 ayat (1) Undang-Undang Yayasan, menyebutkan:

"(1) Pada saat Undang-undang ini mulai berlaku, Yayasan yang:

a. telah didaftarkan di Pengadilan Negeri dan diumumkan dalam Tambahan Berita Negara Republik Indonesia; atau

b. telah didaftarkan di Pengadilan Negeri dan mempunyai izin melakukan kegiatan dari instansi terkait tetap diakui sebagai badan hukum dengan ketentuan dalam jangka waktu paling lambat 3 (tiga) tahun terhitung sejak tanggal Undang-Undang ini mulai berlaku, Yayasan tersebut wajib menyesuaikan Anggaran Dasarnya dengan ketentuan Undang-Undang ini."

Berdasarkan ketentuan di atas bagi yayasan-yayasan yang sudah ada sebelum Undang-undang Yayasan yang telah memenuhi salah satu syarat seperti Pasal 71 tersebut maka tetap diakui sebagai badan hukum dengan syarat yayasanyayasan tersebut wajib untuk menyesuaikan anggaran dasarnya dalam waktu selambat-lambatnya 3 tahun semenjak berlakunya Undang-Undang Yayasan, berarti selambat-lambatnya pada 6 oktober $2008 .^{3}$

Akibat dari pengaturan tersebut, yayasan kemudian dibedakan menjadi dua kelompok, yaitu yayasan-yayasan yang tetap diakui sebagai badan hukum dan

1 H. Subekti, dan Mulyoto, Yayasan Sebelum dan Sesudab Berlakunya Undang-Undang Yayasan dan PP. No. 63 Tahun 2008, Cakrawala Media, Yogyakarta, 2011, hlm. 1.

2 Adib Bahari, Proedur Pendirian Yayasan, Pustaka Yustisia, Yogyakarta, 2010, hlm. 20

3 Mulyoto, Yayasan Periodisasi Dalam Pembuatan Akta, Mal Praktek Dalam Pembuatan Akta, Cakrawala Media, Cetakan II, Yogyakarta, 2018, hlm. 7-8. 
Yayasan-yayasan yang tidak diakui sebagai badan hukum. Berdasarkan pengelompokkan ini, timbul perbedaan kewajiban dan status antara kedua kelompok yayasan tersebut.

Pada 2 Januari 2013 Pemerintah telah mengeluarkan Peraturan Pemerintah Nomor 2 Tahun 2013 tentang Perubahan Atas Peraturan Pemerintah Nomor 63 Tahun 2008 tentang Pelaksanaan Undang-Undang Yayasan. Peraturan tersebut berlaku terhadap yayasan-yayasan yang tetap diakui sebagai badan hukum dan mempunyai kewajiban-kewajiban untuk melakukan penyesuaian dan memberitahukan kepada Menteri agar yayasan tersebut tetap eksis. Berdasarkan kenyataan ini maka yayasan-yayasan yang lahirnya sebelum Undang-Undang Yayasan dikategorikan dalam empat bentuk, yaitu: ${ }^{4}$

a) Yayasan yang tetap diakui sebagai badan hukum dan telah melaksanakan kewajiban-kewajibannya untuk melakukan penyesuaian dan pemberitahuan kepada Menteri.

b) Yayasan yang tetap diakui sebagai badan hukum tetapi belum pernah melakukan penyesuaian terhadap Undang-Undang Yayasan.

c) Yayasan yang tetap diakui sebagai badan hukum dan telah melakukan penyesuaian terhadap Undang-Undang Yayasan, tetapi belum memberitahukan kepada Menteri.

d) Yayasan-yayasan yang tidak diakui sebagai badan hukum.

Yayasan-yayasan yang diakui sebagai badan hukum dan belum pernah melakukan penyesuaian terhadap Undang-Undang Yayasan, maupun yayasan yang tidak diakui sebagai badan hukum dan tidak melakukan penyesuaian sampai 06 Oktober 2008, maka terhadap yayasan-yayasan ini menerima akibat sebagaimana diatur di dalam ketentuan Pasal 71 ayat (4) Undang-undang Yayasan, yaitu tidak boleh menggunakan kata "Yayasan" di depan namanya dan dapat dibubarkan berdasarkan Keputusan Pengadilan atas permohonan Kejaksaan atau pihak yang berkepentingan.

Faktanya praktek di lapangan tidak semulus sebagaimana yang diatur dalam peraturan, terutama untuk dua hal yaitu untuk penyusaian akta yayasan yang didirikan sebelum lahirnya Undang-Undang Yayasan dan masih di akui sebagai badan hukum dan penyesuaian akta yayasan yang didirikan sebelum lahirnya Undang-Undang Yayasan dan tidak lagi diakui sebagai badan hukum.

Pembedaan perlakuan di dalam pembuatan akta sehubungan dengan yayasan sebagaimana diuraikan tersebut di atas ternyata di dalam praktek tidak sepenuhnya diketahui atau dipahami secara benar oleh Notaris. Hal ini mengakibatkan banyak akta-akta dimana pengurus yayasan yang akta

4 H. Subekti dan Mulyoto, Yayasan Sebelum dan Sesudab Berlakunya Undang-Undang Yayasan dan PP. No. 02 Tahun 2013, Cakrawala Media, Yogyakarta, 2018, hlm. 12. 
pendiriannya didirikan sebelum berlakunya Undang-Undang Yayasan, yang kemudian menghendaki agar yayasannya memperoleh status badan hukum atau tetap di akui sebagai yayasan yang berbadan hukum ternyata dibuat secara tidak sesuai dengan peraturan-peraturan mengenai yayasan atau dapat disebut sebagai malpraktek dalam pembuatan akta yayasan. ${ }^{5}$ Kesalahan dalam penyesuaian akta tersebut dapat berakibat buruk. Ini tidak hanya menimbulkan akibat hukum kepada notaris saja, tetapi juga terhadap klien, dan terhadap akta itu sendiri.

Di sisi lain Undang-undang, Peraturan Pemerintah, Peraturan Menteri Hukum dan HAM, bahkan Ikatan Notaris Indonesia (INI) tidak pernah mengeluarkan petunjuk mengenai pembuatan akta penyesuaian. Oleh karena itu, banyak notaris yang seharusnya membuat akta penyesuaian justru membuat akta pendirian yayasan baru. Akibatnya, karena baru sama sekali maka aset yayasan lama sama sekali tidak dimasukkan di akta pendirian yayasan baru.

Berdasarkan latar belakang tersebut, penulis tertarik untuk melakukan penelitian dengan judul "Akibat Hukum Pembuatan Akta Penyesuaian Bagi Yayasan Yang Didirikan Sebelum Lahirnya Undang-Undang Yayasan Yang Tidak Sesuai dengan Peraturan Perundang-undangan".

\section{Rumusan Masalah}

1. Bagaimana tata cara pembuatan akta penyesuaian bagi yayasan yang didirikan sebelum lahirnya Undang-Undang Yayasan?

2. Apakah akibat hukum akta penyesuaian yang pembuatannya tidak didasarkan pada peraturan perundang-undangan tentang yayasan terhadap anggota yayasan, notaris serta terhadap akta yang dibuat?

\section{Tujuan Penelitian}

1. Untuk mengkaji tata cara pembuatan akta penyesuaian bagi yayasan yang didirikan sebelum lahirnya Undang-Undang Yayasan.

2. Untuk menganalisis akibat hukum akta penyesuaian yang pembuatannya tidak didasarkan pada peraturan perundang-undangan tentang yayasan terhadap anggota yayasan, notaris serta terhadap akta yang dibuat.

\section{Metode Penelitian}

Metode yang digunakan dalam penelitian ini adalah penelitian hukum normatif atau penelitian hukum doktrinal ${ }^{6}$ yang menitikberatkan pada

\footnotetext{
5 Mulyoto, "Pertanggungjawaban Notaris-PPAT Dalam Menjalankan Tugas Jabatannya", Cakrawala Media, Cetakan II, Yogyakarta, 2018, hlm.73

${ }^{6}$ Muslan Abdurrahman, Sosiologi dan Metode Penelitian Hukum, UMM Press, Malang, 2009, hlm. 127.
} 
pengamatan terhadap data sekunder. Penelitian ini menggunakan pendekatan perundang-undangan (state approach) dan pendekatan konsep (conceptual approach) dengan a menelaah semua peraturan perundang-undangan dan regulasi yang bersangkut paut dengan isu hukum yang sedang di tangani atau di teliti, dan di padukan dengan pendekatan kasus.

Teknik pengumpulan bahan dengan studi kepustakaan dilakukan untuk menelusuri bahan-bahan hukum. ${ }^{7}$ Untuk memecahkan permasalahan hukum dan sekaligus memberikan preskripsi diperlukan sumber-sumber penelitian ${ }^{8}$, sumbersumber penelitian hukum tersebut terdiri dari:

1. Bahan Hukum Primer, yakni merupakan bahan hukum yang bersifat landasan hukum. Dalam penulisan jurnal ini, bahan hukum primer yang digunakan adalah:

1) Kitab Undang-Undang Hukum Perdata

2) Undang-Undang Nomor 16 Tahun 2001 tentang Yayasan

3) Undang-Undang Nomor 28 Tahun 2004 tentang Perubahan atas UndangUndang Nomor 16 Tahun 2001 tentang Yayasan.

4) Peraturan Pemerintah Nomor 63 Tahun 2008 tentang Pelaksanaan UndangUndang tentang Yayasan.

5) Peraturan Pemerintah Nomor 2 Tahun 2013 tentang Perubahan Peraturan Pemerintah Nomor 63 Tahun 2008 tentang Pelaksanaan Undang-Undang tentang Yayasan

6) Undang-Undang Nomor 2 Tahun 2014 tentang Perubahan atas UndangUndang Nomor 30 Tahun 2004 tentang Jabatan Notaris

2. Bahan Hukum Sekunder, yakni memberikan penjelasan mengenai bahan hukum primer berikut hal-hal yang berkaitan dengan isi bahan hukum primer. Dalam penelitian ini bahan hukum sekunder yang digunakan adalah berbagai buku, jurnal hukum dan sumber-sumber dari internet yang membahas mengenai akta penyesuaian yayasan.

3. Bahan Hukum Tersier, yakni bahan yang memberikan petunjuk maupun penjelasan terhadap bahan hukum primer dan bahan hukum sekunder. Dalam penulisan tesis ini yang digunakan adalah Kamus Hukum dan Kamus Besar Bahasa Indonesia.

\footnotetext{
${ }^{7}$ Beni Ahmad Saebani, Metode Penelitian Hukum, Pustaka Setia, Bandung, 2008, hlm. 57.

8 Peter Mahmud Marzuki, Penelitian Hukum, Kencana Prenada Media Group, Jakarta, 2010, hlm. 181.
} 


\section{Hasil Penelitian dan Pembahasan}

\section{Pembuatan Akta Penyesuaian bagi Yayasan yang Didirikan Sebelum Lahirnya Undang-Undang Yayasan}

Demi memudahkan masyarakat mendaftarkan perubahan anggaran dasar yayasannya dalam rangka penyesuaian terhadap perubahan Undang-undang Yayasan, pemerintah mengeluarkan Peraturan Pemerintah Nomor 2 Tahun 2013 tentang perubahan atas Peraturan Pemerintah Nomor 63 Tahun 2008 tentang pelaksanaan Undang-Undang tentang Yayasan. Penyesuaian akta ini yaitu menyesuaikan akta pendirian atau anggaran dasar dengan peraturan perundangundangan sehubungan dengan yayasan. Apabila menyesuaikannya menghadap notaris sesudah berlakunya Peraturan Pemerintah Nomor 02 Tahun 2013, maka terdapat 2 pilihan yakni sebagai berikut.

Pertama, didasarkan pada Pasal 15A Peraturan Pemerintah Nomor 2 Tahun 2013 yang berbunyi berikut.:

Dalam hal permohonan pengesahan akta pendirian Yayasan sebagaimana dimaksud dalam Pasal 15 ayat (1) dan kekayaan awal Yayasan berasal dari Yayasan yang sudah tidak dapat menggunakan kata "Yayasan" di depan namanya, permohonan pengesahan dilampiri:

a. Salinan akta pendirian Yayasan yang dalam premise aktanya menyebutkan asalusul pendirian Yayasan termasuk kekayaan Yayasan yang bersangkutan;

b. Laporan kegiatan Yayasan paling sedikit selama 5 (lima) tahun terakhir secara berturut-turut yang ditanda-tangani oleh Pengurus Yayasan dan diketahui oleh instansi terkait;

c. Surat pernyataan Pengurus Yayasan bahwa Yayasan tidak pernah dibubarkan secara sukarela atau berdasar putusan pengadilan;

d. Fotokopi Nomor Pokok Wajib Pajak Yayasan yang telah dilegalisir oleh Notaris;

e. Surat pernyataan tempat kedudukan disertai alamat lengkap Yayasan yang ditandatangani oleh Pengurus Yayasan dan diketahui oleh lurah atau kepala desa setempat;

f. Pernyataan tertulis dari Pengurus Yayasan yang memuat keterangan nilai kekayaan pada saat penyesuaian Anggran Dasar;

g. Surat pernyataan Pengurus mengenai keabsahan kekayaan Yayasan; dan

h. Bukti penyetoran biaya pengesahan dan pengumuman Yayasan.

Pasal 15A tersebut menyebutkan bahwa akta penyesuaian yayasan tersebut di atas termasuk merupakan perlakuan terhadap yayasan yang didirikan sebelum berlakunya undang-undang yayasan. Yayasan ini termasuk yayasan yang tidak diakui sebagai badan hukum yang sampai saat ini atau saat pengurus yayasan menghadap notaris belum ada ada atau tidak menyesuaikan anggaran dasarnya dengan Undang-Undang Yayasan.

Pasal 15A di atas juga menyebutkan mengenai lampiran-lampiran yang harus dilengkapi oleh yayasan yang sudah tidak dapat menggunakan kata 
"Yayasan" di depan namanya atau yayasan yang telah dianggap "tidak ada" lagi karena tidak boleh menggunakan nama "Yayasan" di depan namanya untuk mendapatkan pengesahan akta pendirian yayasan oleh Menteri agar memperoleh status badan hukum.

Kedua, didasarkan pada Pasal 37A Peraturan Pemerintah Nomor 2 Tahun 2013 dimana Yayasan yang telah berbadan hukum namun belum melakukan penyesuaian atas anggaran dasarnya terhadap undang-undang dapat melakukan penyesuaian tersebut, dengan syarat:

a) Paling sedikit selama 5 tahun berturut-turut sebelum penyesuaian anggaran dasar masih melakukan kegiatan sesuai Anggaran Dasarnya; dan

b) Belum pernah dibubarkan ${ }^{9}$

Berdasarkan hal tersebut, yayasan yang akan melakukan penyesuaian dengan Undang-Undang Yayasan, khususnya bagi yayasan yang tetap diakui sebagai badan hukum yang sampai dengan saat ini belum menyesuaikan dengan Undang Undang Yayasan, prosesnya yaitu penyesuaian anggaran dasar terhadap undang-undang Yayasan dilakukan berdasarkan rapat pleno pengurus lengkap dengan agenda tunggal yaitu penyesuaian anggaran dasar yayasan berdasarkan peraturan perundang-undangan yang berlaku. Setelah rapat memutuskan untuk menyetujui usulan penyesuaian tersebut selanjutnya dilaksanakan penyesuaian dengan cara merubah semua pasal-pasal anggaran dasar dan sekaligus menentukan susunan organ yayasan yang terdiri dari Pembina, Pengurus dan Pengawas Yayasan dan mencantumkan susunan organ yayasan tersebut di dalam pasal penutup dari anggaran dasarnya. Dari hasil rapat tersebut dibuatlah berita acara rapat yang ditandatangani Ketua Rapat dan Sekretaris. Tata cara dalam pelaksanaan Rapat Pleno Pengurus Yayasan dalam rangka penyesuaian anggaran dasar Yayasan sebagai berikut: 10

a) Ketua atau minimal $1 / 2$ dari anggota Pengurus yang berhak untuk mengusulkan agar diadakan Rapat Pengurus Yayasan.

b) Untuk rapat-rapat tertentu dalam mengadakan Perubahan Anggaran Dasar atau rapat-rapat yang penting seperti penyesuaian anggaran dasar yayasan dengan undang-undang yayasan dimana agenda rapatnya adalah tunggal atau satu agenda dan minimal dihadiri oleh $3 / 4$ dari jumlah anggota Dewan Pengurus dan keputusan rapat diambil berdasarkan permufakatan dalam musyawarah atau berdasarkan suara terbanyak.

Apabila salah seorang pengurus Yayasan sudah diundang rapat sampai 2 kali secara sah namun ternyata tetap tidak hadir yaitu apabila jumlah pengurus

9 Mulyoto, Op. Cit., hlm 12.

10 Henricus Subekti dan Mulyoto, Op. Cit., hlm. 26. 
yang hadir telah terpenuhi kuota rapat umum minimal dimana kehadiran untuk keperluan diadakannya rapat tersebut, maka rapat tetap dapat dilanjutkan atau dapat tetap dilaksanakan. Demikian juga rapat tetap dapat mengambil keputusan yang sah dan mengikat kalau jumlah pengurus yang menyetujui lebih banyak daripada yang tidak menyetujui lebih banyak daripada yang tidak menyetujui, yaitu dalam hal Anggaran Dasar Yayasan ditentukan keputusan berdasar suara terbanyak atau musyawarah apalagi apabila semua yang hadir menyetujui berarti keputusan telah diambil dengan suara bulat. ${ }^{11}$

Berdasarkan hal tersebut di atas, setelah itu dilakukan rapat pleno pengurus yayasan dimana apabila rapat tersebut dihadiri oleh notaris, maka berita acara rapat itulah yang nantinya akan dikirimkan kepada menteri sebagai laporan. Namun, apabila rapat tersebut tidak dihadiri oleh notaris, maka penerima kuasa yang diberikan oleh rapat pleno pengurus lengkap Yayasan tersebut datang menghadap kepada notaris untuk menuangkan isi keputusan rapat tersebut ke dalam akta notaris (akta pernyataan keputusan rapat). Selanjutnya akta tersebut beserta lampiran-lampirannya sebagaimana disyaratkan dalam Pasal 37 A ayat (4) Peraturan Pemerintah Nomor 2 Tahun 2013 dikirimkan kepada Menteri Hukum dan HAM Republik Indonesia sebagai pemberitahuan atau laporan perubahan anggaran dasar yayasan. Surat penerimaan pemberitahuan perubahan anggaran dasar yayasan oleh menteri tersebut kemudian dikirim ke yayasan melalui notaris yang membuat akta berita acara rapat atau atau pernyataan keputusan rapat. ${ }^{12}$ Tugas notaris dalam membuat akta perubahan anggaran dasar berdasarkan Pasal 37A tersebut ialah menyesuaikan anggaran dasar yayasan dengan ketentuan undang-undang yayasan dan peraturan pemerintah dengan cara membuat "Pernyataan Keputusan Rapat Pleno Pengurus Lengkap Yayasan..." atau dengan membuat "Berita Acara Rapat Pleno Pengurus Lengkap Yayasan...."

\section{Akibat Hukum Penyesuaian yang Tidak Mendasarkan pada Peraturan Perundang-Undangan Yayasan terhadap Anggota Yayasan, Notaris dan Akta yang Dibuat}

Akibat hukum penyesuaian yang tidak mendasarkan peraturan perundangundangan yayasan terhadap anggota yayasan dapat menyebabkan pihak tersebut dikenakan 3 Pasal Tindak Pidana. Pertama, jika anggota organ yayasan, pada waktu menghadap notaris (membuat akta pendirian yayasan baru) tersebut menggunakan NPWP Yayasan lama, maka dapat mengarah pada pemalsuan NPWP. Oleh karena itu dapat dikenakan Pasal 264 KUHP tentang pemalsuan surat dengan ancaman pidana penjara paling lama delapan tahun, jika pemalsuan 
dilakukan terhadap akta-akta autentik. Kedua, anggota organ yayasan yang baru tersebut menunjukkan atau menguasai atau menggunakan aset-aset yayasan atau kekayaan yayasan yang lama yang didirikan sebelum lahirnya undang-undang yayasan, yang kemudian adalah termasuk" penguasaan aset tanpa hak" (ini juga termasuk tindak pidana). Oleh karena itu, dapat dikenakan Pasal 385 KUHP yang mana jika seseorang dengan maksud untuk menguntungkan diri sendiri atau orang lain dengan melawan hak (secara tidak sah) menjual, menukar, atau menjadikan tanggungan utang hak orang lain untuk memakai tanah negara, maka dapat dihukum penjara selama 4 tahun penjara. Ketiga, anggota organ yayasan yang baru tersebut mengklaim bahwa yayasan yang berdasarkan akta pendirian yayasan yang baru tersebut adalah merupakan perubahan atau kelanjutan dari yayasan yang lama (yang didirikan sebelum lahirnya Undang-Undang Yayasan), maka dikategorikan melakukan pembohongan terhadap publik.

Tidak hanya anggota yayasan, notaris juga dapat dibebani tanggung jawab baik secara perdata maupun administrasi terhadap kebenaran akta yang dibuatnya. Notaris dapat dituntut ganti rugi harga dan biaya atas kerugian para pihak yang berkepentingan terhadap yayasan tersebut. Ini sesuai dengan Pasal 16 ayat (12) Undang-Undang Nomor 2 Tahun 2014 tentang Perubahan Atas UndangUndang Nomor 30 Tahun 2004 tentang Jabatan Notaris, bahwa selain dikenai sanksi sebagaimana dimaksud pada ayat (11), pelanggaran terhadap ketentuan Pasal 16 ayat (1) huruf $j$ dapat menjadi alasan bagi pihak yang menderita kerugian untuk menuntut penggantian biaya, ganti rugi, dan bunga kepada Notaris (sesuai dengan Pasal 1365 KUHPdt). Hal ini juga sesuai dengan Pasal 84 Undang-Undang Jabatan Notaris bahwa tindakan pelanggaran yang dilakukan oleh Notaris terhadap ketentuan sebagaimana yang dimaksud oleh Undang-Undang yang mengakibatkan suatu akta hanya mempunyai kekuatan pembuktian sebagai akta dibawah tangan atau suatu akta menjadi batal demi hukum dapat menjadi alasan bagi pihak yang menderita kerugian untuk menuntut penggantian biaya, ganti rugi, dan bunga kepada Notaris. Secara administratif, notaris yang terbukti melanggar kode etik dapat diberikan sanksi mulai dari teguran lisan, teguran tertulis bahkan sampai dengan pemberhentian dengan tidak hormat. Hal ini sebagaimana disebutkan dalam Pasal 16 ayat (11) dan ayat (12) Undang-Undang Jabatan Notaris.

Penyesuaian yang tidak mendasarkan peraturan perundang-undangan dapat pula menimbulkan akibat tertentu terhadap akta yang dibuat. Akta yang dibuat oleh notaris termasuk ke dalam akta autentik. Akta autentik merupakan suatu akta yang dibuat oleh atau dihadapan pegawai-pegawai umum yang 
berkuasa untuk itu di tempat di mana akta dibuatnya".13 Berdasarkan pengertian tersebut, maka keabsahan akta autentik adalah harus dibuat sesuai perundangundangan yang berlaku. Dengan demikian, akibat hukum terhadap akta yang dibuat oleh Notaris yang tidak sesuai atau bertentangan dengan Undang-Undang Yayasan adalah batal demi hukum. Akta tersebut juga dapat dibatalkan oleh pihak yang berkepentingan dalam hal misalnya subyek penghadapnya tidak terpenuhi legal standingnya atau kurang lengkap seperti ketika tidak semua mantan pengurus hadir dalam rapat pengurus yayasan lengkap menjelang penyesuaian.

\section{Penutup}

Berdasarkan hasil penelitian dan pembahasan dapat ditarik kesimpulan sebagai berikutL pertama, Yayasan yang di didirikan sebelum lahirnya UndangUndang Yayasan tersebut dapat disesuaikan melalui dua pilihan, yaitu dengan mendasarkan Pasal 37A atau Pasal 15A Peraturan Pemerintah Nomor 2 Tahun 2013. Terhadap yayasan yang didirikan sebelum lahirnya undang undang yayasan yang masih diakui sebagai badan hukum berlaku Pasal 37 A, sedangkan terhadap yayasan yang didirikan sebelum lahirnya undang undang yayasan yang sudah tidak diakui sebagai badan hukum penyesuaiannya didasarkan Pasal 15A Peraturan Pemerintah Nomor 2 Tahun 2013. Kedua, penyesuaian yang tidak didasarkan pada peraturan perundang-undangan yayasan dapat menimbulkan akibat hukum tertentu. Terhadap anggota yayasan dapat berakibat pada pemidanaan terhadap tiga tindak pidana yaitu pemalsuan nomor pokok wajib pajak (NPWP), penguasaan aset yang tanpa hak, dan pembohongan publik. Terhadap notaris yang melanggar administrasi dapat dikenakan sanksi yaitu peringatan tertulis, pemberhentian sementara, pemberhentian dengan hormat, atau pemberhentian dengan tidak hormat. Selain itu notaris dapat pula digugat secara perdata karena melanggar Pasal 1365 KUHPdt. Terhadap Akta yang di buat oleh notaris dapat batal demi hukum karena akta tersebut tidak mendasarkan dengan peraturan perundang-undangan.

Saran yang di ajukan oleh penulis yaitu untuk notaris dan calon notaris agar dalam menyesuaikan Anggaran Dasar sesuai dengan peraturan perundangundangan.

\section{Daftar Pustaka}

\section{Buku}

Adib, Bahari, Prosedur Pendirian Yayasan, Pustaka Yustisia, Yogyakarta, 2010.

\footnotetext{
13 Pasal 1868 KUHPerdata
} 
Habib, Adjie dan Muhammad Hafidh, Yayasan Memahami Pendirian Perubahan Pembubaran Yayasan Sebelum dan Sesudah Berlakunya Undang-Undang Nomor 16 Tahun 2001 tentang Yayasan, PT. Citra Aditya Bakti, Bandung, 2016.

Marzuki Peter, Mahmud, Penelitian Hukum, Kencana Prenada Media Group, Jakarta, 2010.

Mulyoto dan H. Subekti, Yayasan Sebelum dan Sesudah Berlakunya Undang-Undang Yayasan dan PP. No. 02 Tahun 2013, Cakrawala Media, Yogyakarta, 2018. Yayasan Sebelum dan Sesudah Berlakunya Undang-Undang Yayasan dan PP. No. 63 Tahun 2008, Cakrawala Media, Yogyakarta, 2011.

, "Pertanggungjawaban Notaris-PPAT dalam menjalankan tugas jabatannya", Cakrawala Media, Cetakan II, Yogyakarta, 2018.

Muslan, Abdurrahman, Sosiologi dan Metode Penelitian Hukum, UMM Press, Malang, 2009.

Saebani Beni, Ahmad, Metode Penelitian Hukum, Pustaka Setia, Bandung, 2008.

\section{Peraturan Perundang-Undangan}

Kitab Undang-Undang Hukum Perdata

Undang Undang Nomor 28 Tahun 2004 tentang Perubahan Atas Undang Undang Nomor 16 Tahun 2001 Tentang Yayasan

Peraturan Pemerintah Republik Indonesia Nomor 2 Tahun 2013 tentang Perubahan atas Peraturan Pemerintah Nomor 63 Tahun 2008 tentang pelaksanaan Undang Undang Yayasan 